\title{
IT solutions supporting project management processes and the choice of software
}

\author{
Anna Kaczorowska ${ }^{1, *}$, Jolanta Słoniec ${ }^{2}$, and Sabina Motyka $^{3}$ \\ ${ }^{1}$ University of Lodz, Faculty of Management, Department of Computer Science, Matejki 22/26, 90-237 Łodz, Poland \\ ${ }^{2}$ Lublin University of Technology, Faculty of Management, Department of Enterprise Organization, Nadbystrzycka 38, 20-618 \\ Lublin, Poland \\ ${ }^{3}$ Cracow University of Technology, Faculty of Mechanical, Department of Manufacturing Processes, M6 Institute, Jana Pawła \\ II 37 Avenue, 31-864 Cracow, Poland
}

\begin{abstract}
The article aims to present both the theoretical contents and proposed solutions to practical problems perceived in the support of project management. The process' approach was recommended as the basis of project management. The classification of instruments due to the implemented functions and structure of information systems, which support project management, was included, in conjunction with the type of projects handled. The maturity of project management information support was analysed. Project management areas that have the highest possibilities of information support were indicated, and a list of advantages of the use of information instruments was drawn up. Both the main criteria of software selection and the basic requirements presently formulated with reference to project management supporting systems were determined.
\end{abstract}

\section{Introduction}

The development of information systems for project management evolved from the supporting tools, in a rather narrow range, the work of just one person in a single project for solutions that assure the cooperation of many subjects in a multi-project environment [1, 2, 3, 4].

Presently, project managers and project teams mostly plan and control the accomplishment of undertakings as well as their reporting and documenting using information instruments. Information tools also assure a partial support of the processes of a projects initiation and definitions, project team organization, and administration of the results and collection of the project knowledge [5].

The software which supports the project management may increase the effectiveness of concrete project management, but it will never compensate for factual, methodical or organizational deficiencies occurring in the project implementing organization. Heerkens expressed this as follows: "The use of planning software without understanding of the essence of project management allows merely to create faster some lousy schedules" [6].

The use of an appropriate information infrastructure contributes to the enhanced quality of the management processes, including project management processes [2].

The information infrastructure of project management (IIZP) should be perceived as a platform that enables the functioning of project management and use of hard and soft instruments of management dedicated to that area.
IIZP consists of the following components: hardware, software, resources of information, knowledge ${ }^{1}$, models ${ }^{2}$ and procedures related to projects and networks. Owing to IIZP, new information systems for project management (ISfPM) arise. Contractors and people responsible for the project results and users who can use such instruments may significantly increase not only the capacity of their work, but also the reliability of undertaken decisions. They may also increase the chances of success in the project implementation.

However, the information system is only one part of the project management system. Its application depends on the project requirements related to IIZP and the scope in which the IIZP could support project management.

Despite the constantly growing level of advancement in an information system, they are not autonomic enough to independently specify more accurately the project goals and risks, and automatically organize the project team. However, the use of a properly chosen ISfPM may constitute an effective support of the decisive processes on all levels of the organization, by facilitated planning of the projects and controlling the correctness of their performance [7].

\footnotetext{
${ }^{1}$ Bases of knowledge enable the management of knowledge and decision-taking in extraordinary conditions.

${ }^{2}$ Models are gathered in the models base allowing for simulation of the consequences of undertaking various decisions.
} 


\section{The process model of project management}

The increased interest in the process approach recently resulted from aspiring to meet the accomplishment of the buyers' expectations within very intensive competition. This approach pulls to the fore the dynamic aspects and process harmonization of activities and focuses on process effects $[8,9,10,11,12]$.

Processes are the sets of consecutive activities in cause and effect relations to each other, carried out with the aim to reach the intended result (product, service), constituting in satisfaction of the client's important external or internal needs [5]. Consequently, projects are actually processes. Therefore, the projects management should be based on the process approach - its principles, models and methods [8].

Thus, an appropriate model for a projects presentation is the process model, because it enables a complete description of dynamic organizational phenomena, i.e. the projects.

The process model contains three main groups of project processes: executive processes, supportive processes and managerial processes.

Executive processes of the project (otherwise referred to as the operative or primary processes) have a direct share in the creation of the intended result product and service. At the input of such processes, there are always concrete needs, whereas at the output - as an effect, the satisfaction of such needs should always occur. Executive processes are divided into two types: processes of designing the project's result (creative consisting of a description, usually in the form of project documentation, intended result of the project) and project implementation processes (referring to the material implementation of the product/service of the project).

The project supporting processes - servicing or auxiliary - do not have any direct share in creating the project's outcome, but they create the conditions to achieve it. They comprise the processes of legal, staffrelated, financial and accounting, informative, technological, and administrative support. The list of the project supporting processes is open and each time adjusted to the specific undertaking.

Managerial processes consist of harmonization of executive processes and supporting processes with the aim to reach the intended result of the project. Managerial processes include the processes of outlining the goals, organization and motivation, and control.

For every group of processes, i.e. executive, supporting and managerial processes we can determine a separate model structure (cycle) constituting a pattern of its course, repetitive in various projects. This allows us to formulate general principles and guidelines and use universal methods of project planning and implementation.

Recognition of repetitiveness of the projects model structure allows us to define those structures as cyclic ones. Therefore, in project management we deal with the projects lifecycle (cycle of projects), projects management cycle, cyclic processes of support (Figure 1).

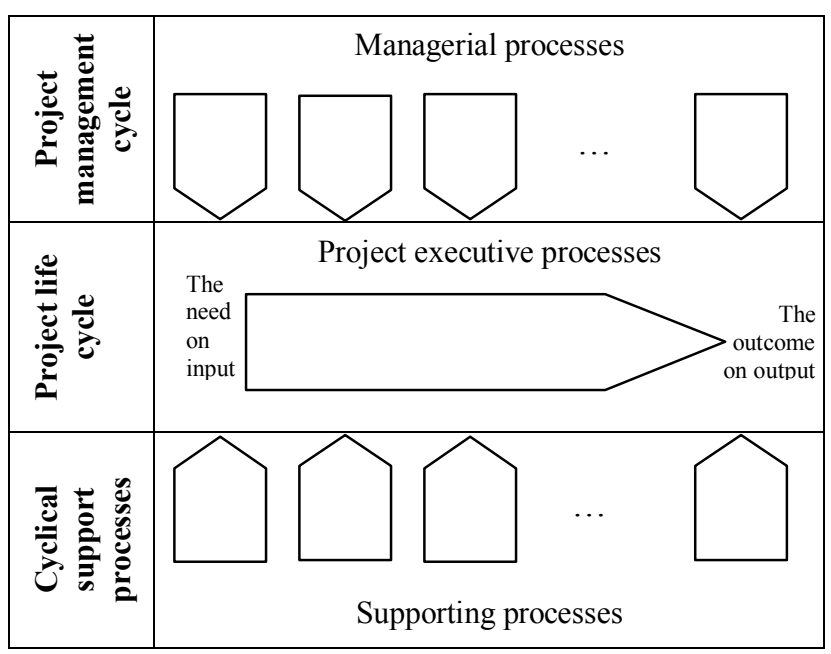

Fig. 1. General process model of project implementation (own preparation on the basis of $[5,13])$.

In view of the diversity of projects, which is mostly manifested in their executory process, the search for a universal generalized model, which would describe the lifecycle of all projects, seems of little use. The effort is focussed on the development of the models of the respective types of projects, e.g. information projects, constructional projects, complex technological devices, and research \& developmental projects [14].

The project management cycle is a generalized (model) presentation of the course of the project managerial process. This concept is based on the assumption that, despite a considerable differentiation of the goals and diversity of the projects' results, we can determine their common set of managerial processes. According to this concept $[5,13]$, the project management cycle consists of four phases (defining DP, preparation - PP, workmanship - WP, finishing - FP) and eight managerial processes:

1) Initiation and definition of the project (DP),

2) Organizing a project team (PP),

3) Planning the project structure (PP),

4) Planning the project terms (PP),

5) Planning the project resources (PP),

6) Organization of the project performance (PP),

7) Guidance (control and coordination) of preparation of the performance of the project and actual performance of the project (WP),

8) Closure of the project (FP).

The structure of the project management cycle varies among different methodological standards [15].

Singling out three main groups of processes and their model structures, repeated periodically and forming a closed entirety, is of crucial importance for project management. It enables the description of the most important processes connected with project implementation. Therefore, the process' approach is recommended as the basis of improving the project management process, important for increasing the efficiency of the functioning of contemporary organizations $[5,9,13]$. 


\section{Classifications of information systems for project management and their maturity}

Information systems for project management (ISfPM) may be qualified to one of the following three classes [5]:

1) Project Management Support Systems - PMS,

2) Project Portfolio Management - PPM [16, 17],

3) dedicated tools and packages [18].

The functions, which should be accomplished by information systems of particular classes, are presented in Table 1.

Table 1. Functions implemented by particular classes of systems for project management (own work based on $[1,3,5$, $16,19])$.

\begin{tabular}{|c|c|}
\hline ISfPM class & Functionality of the system \\
\hline PMS & $\begin{array}{l}\text { - Project planning support } \\
\text { - Tasks management - preparation of the } \\
\text { Work Breakdown Structure; determination } \\
\text { of four types of relations between the } \\
\text { current task and its preceding task: Finish } \\
\text { to Start, Start to Start, Finish to Finish, } \\
\text { Start to Finish; recognition of various } \\
\text { types of tasks, such as: milestones, } \\
\text { individual tasks, summary tasks, work } \\
\text { packages; checking the status of single } \\
\text { tasks and groups of tasks; generation of } \\
\text { lists of particularly important activities, } \\
\text { those with approaching accomplishment } \\
\text { deadline, delayed activities or those } \\
\text { threatened with a delay; implementation of } \\
\text { the method of critical path; budgeting of } \\
\text { tasks } \\
\text { - Management of resources - records and } \\
\text { assignment of resources for } \\
\text { accomplishment of concrete tasks; } \\
\text { analysis of loading the resources with } \\
\text { work; signalling an excessive allocation of } \\
\text { resources; calculation of resources work } \\
\text { costs; } \\
\text { - Views and reports - for various } \\
\text { participants of the project with a } \\
\text { possibility of their independent } \\
\text { preparation and adjustment to concrete } \\
\text { needs }\end{array}$ \\
\hline PPM & $\begin{array}{l}\text { - Coordination of tasks and allocation of } \\
\text { resources at the level of the whole } \\
\text { organization } \\
\text { - Establishing the priorities for projects } \\
\text { - Management of the projects portfolio } \\
\text { risk } \\
\text { - Management of users' rights } \\
\text { - Processing larger data sets than those } \\
\text { with the use of PMS } \\
\text { - Group work using coordination packages } \\
\text { of the group work - groupware } \\
\text { - Multidimensional data analyses in OLAP } \\
\text { technology }\end{array}$ \\
\hline $\begin{array}{l}\text { Dedicated tools } \\
\text { and packages } \\
\text { (DTaP) }\end{array}$ & $\begin{array}{l}\text { - Advanced reporting in the language and } \\
\text { currency of a given country, including the } \\
\text { locally used measurement system, legal } \\
\text { regulations of the activity of the project } \\
\text { conducting organisation }\end{array}$ \\
\hline
\end{tabular}

From the point of view of the users working within one project, the PPM system functionality basically does not differ from the PMS system. Specific functions of PPM systems are used by the entities responsible for project coordination at a higher organizational level, e.g. strategic design offices or program managers or corporation projects portfolio.

Dedicated tools and packages are usually formed for the needs of concrete enterprises. Such programs should then meet all the needs connected with the project implementation. The use of specialist software may, among others, result from local conditions, specificity of the project or the area of the project which engages an organization from the branch in which the project manager is functioning. From the necessity to integrate the dedicated system with the information systems so far used in the organisation [18].

The use of various classes of systems for project management may be referred to the organization's project maturity levels [12, 17, 20, 21]. Classification suggested by Gasik [22] exhibits ascending nature in which each higher level contains the functionalities of lower levels and elements that are specific for itself.

The article omits Level 0, i.e. manual level, because the main information tool used on this level is the office software, such as: Ms Excel or Ms Word.

Level 1 - individual - is the first level on which information systems are used in project management. The software, which supports the project management, is used independently in respective projects, without communication inside the project portfolio or with other areas of organizational management. The project management support on this level comprises the creation of the Work Breakdown Structure (WBS), preparing the schedule, records of the progress of work, planning and records of costs, the analysis of the worked out value, and supervision of the project implementation. It is possible to transform the schedule into a plan through the allocation of resources, but software does not support the resources management because it does not contain any information about the use of resources in other projects. The way of using the information instruments depends on the project manager and, therefore, working time records are not kept in the system, especially when the resources work in many projects. The Ms Project Standard or Professional software in a one-stand version is most often used on this maturity level.

A Level 2 portfolio assumes the mutual management with the entire portfolio of all projects of the organization. ISfPM maintains one common repository, i.e. all dictionaries necessary to implement the projects. The most important dictionaries comprise dictionary of the types of projects, organizational structure, pool of the organization's resources, dictionary of the resource roles in projects, WBS templates, bookkeeping accounts structure, types of risks, and users' rights in the system. The most important functions implemented by ISfPM on this maturity level are working time records, supporting the common management of resources, mutual analyses of a projects performance, supporting of inter-project communication, supporting uniform reporting and unified standards of projects implementation. Among the 
systems available on the market, the Primavera tools support the portfolio management best.

Level 3 - Integrated, requires the used ISfPM to be integrated with the organization's most important information systems which comprise the financial and accounting system - FK, human resources management system - HRMS, electronic information flow system EIFS, customer relationship management system CRMS, shopping support system - SSS, production support system - PSS. Information systems at this maturity level enable bilateral communication (ISfPM $\longrightarrow$ concrete information system of the organization). They provide, through electronic mail or internet portals, information about the costs generated by the resources (for FK), type and evaluation of performed work (HRMS), contacts with project clients (CRM) and the status of conducted tasks (PSS). Presently, organizations planning to reach this maturity level must work out themselves the interfaces between individual systems. The existing ready solution - the closest to the requirements of the integrated level, is the SAP software (SAP Business One - Project Management).

Level 4 - Uniform, is characteristic of enterprises which have one application supporting all areas of the organization's management. All functions, which the organization needs for project management, are supported in one database. The organization's human resources and contractor in the project mean the same resource, described as one record in the base. There is no need to develop an interface and synchronisation with the FK system, because from the project level there is direct access to the accounts plan. Presently, there are no ready solutions that support project management at a uniform level.

Table 2. Maturity levels of ISfPM (own preparation on the basis of $[5,17,22])$.

\begin{tabular}{|c|c|c|c|c|}
\hline \multirow{2}{*}{$\begin{array}{c}\text { ISfPM } \\
\text { class }\end{array}$} & \multicolumn{4}{|c|}{ Maturity level of the system } \\
\cline { 2 - 5 } & $\mathbf{1}$ & $\mathbf{2}$ & $\mathbf{3}$ & $\mathbf{4}$ \\
\hline $\mathrm{PMS}$ & + & - & - & - \\
\hline $\mathrm{PPM}$ & - & + & + & partly \\
\hline $\mathrm{DTaP}$ & + & + & + & - \\
\hline
\end{tabular}

Table 2 qualified ISfPM of a specific class to an appropriate level of maturity. Sign , ," stands for an achievement, whereas ,-" is a failure to achieve a given maturity level by the system.

From the point of view of the organization that seeks the most appropriate ISfPM, the most important seems to be the classification involving technical issues of location of the programme, which distinguishes [23]:

1) Programs installed on the local server and users' computers,

2) Tools accessed through the Web interface,

3) Software as a Service (SaaS), i.e. the software provided by the network without the need of installation and maintenance of servers on the clients' part [24].

\section{Advantages of IT support in project management}

The share of respective phases of the project management cycle in the project's inputs and costs is differentiated. It will be mentioned after the results of the costing structure analysis with the participating 364 project management practitioners from the organizations which, within one year, carried out 16,110 projects for the total amount of $\$ 29.8 \mathrm{~b}$ [25].

The defining phase lasts from several days to several weeks, its costs amounting to approx. $12 \%$. The duration of the consecutive phase, i.e. preparatory phase is counted, (depending on the project complexity) in weeks, months and even years, its share in the project expenditures and costs amounting to about $20 \%$. The performance phase is mainly the project implementation process, which is accompanied by the management processes of operation (control and coordination). This phase usually takes the majority of the time and the biggest cost of the project: performance - approx. $43 \%$, operation - approx. $18 \%$. The last phase - termination, lasts from several days to several months, its share in expenditures and costs amounts to approx. 7\% [25].

Knowing the distribution of expenditures and costs between phases, it seems reasonable to seek software which would support the most difficult and expensive processes in the projects management cycle. Table 3 lists the advantages of information support of the processes occurring in the respective phases.

Table 3. Advantages of information support of individual processes of the project management cycle (own work based on $[2,5,9,19,25])$.

\begin{tabular}{|l|l|}
\hline $\begin{array}{c}\text { Supported } \\
\text { processes within } \\
\text { phases }\end{array}$ & \multicolumn{1}{c|}{ Advantages of support } \\
\hline $\begin{array}{l}\text { Initiation and } \\
\text { definition of the } \\
\text { project (defining } \\
\text { phase) }\end{array}$ & $\begin{array}{l}\text { - Taking the decision as to the date } \\
\text { of starting or finishing on which } \\
\text { the schedule of the project will be } \\
\text { based and hence - what operations } \\
\text { of the program will be undertaken } \\
\text { - Preparing the definition or } \\
\text { synthetic description of the project } \\
\text { - Analysis of risk }\end{array}$ \\
\hline $\begin{array}{l}\text { Planning the } \\
\text { project structure } \\
\text { (preparatory phase) }\end{array}$ & $\begin{array}{l}\text { - More precise distribution of } \\
\text { works in the project, involving the } \\
\text { most important factors affecting } \\
\text { the result of the project }\end{array}$ \\
\hline $\begin{array}{l}\text { Planning the dates } \\
\text { preparatory phase) }\end{array}$ & $\begin{array}{l}\text { - Reduction of the schedule } \\
\text { development time } \\
\text { - More effective arrangement of } \\
\text { dates with the project participants } \\
\text { - Assignment of a critical path }\end{array}$ \\
\hline $\begin{array}{l}\text { Planning the } \\
\text { resources } \\
\text { (preparatory phase) }\end{array}$ & $\begin{array}{l}\text { - Clear determination of } \\
\text { contractors' tasks and } \\
\text { responsibilities } \\
\text { - More optimum use of resources } \\
\text { - Signalling an excessive } \\
\text { allocation of resources and the so } \\
\text { called ,bottlenecks" }\end{array}$ \\
\hline
\end{tabular}




\begin{tabular}{|c|c|}
\hline $\begin{array}{c}\text { Supported } \\
\text { processes within } \\
\text { phases }\end{array}$ & Advantages of support \\
\hline $\begin{array}{l}\text { Planning the costs } \\
\text { (preparatory phase) }\end{array}$ & $\begin{array}{l}\text { - Reliable determination of costs } \\
\text { for project-related works according } \\
\text { to their original sources } \\
\text { - Realistic calculation of planned } \\
\text { costs and budgeting } \\
\text { - Isolation of reserves (e.g. for risk } \\
\text { management) in the project budget } \\
\text { - Limitation of agreed penalties } \\
\text { - Decreased freezing of capital }\end{array}$ \\
\hline $\begin{array}{l}\text { Organization of the } \\
\text { project } \\
\text { (preparatory phase) }\end{array}$ & $\begin{array}{l}\text { - Faster communication between } \\
\text { the project participants } \\
\text { - On-going work of the team }\end{array}$ \\
\hline $\begin{array}{l}\text { Operation of the } \\
\text { project } \\
\text { (performance } \\
\text { phase) }\end{array}$ & $\begin{array}{l}\text { - Specification of the project } \\
\text { evaluation indices } \\
\text { - Recording the working time } \\
\text { - Precise control of progress in the } \\
\text { project at the time close to real } \\
\text { time } \\
\text { - Lower expenditures on the } \\
\text { project operation } \\
\text { - Faster response to deviations } \\
\text { from the plan or changes of the } \\
\text { plan } \\
\text { - Increased transparency of the } \\
\text { course of the project }\end{array}$ \\
\hline $\begin{array}{l}\text { Analysis of results } \\
\text { and collection of } \\
\text { project knowledge } \\
\text { (completion phase) }\end{array}$ & $\begin{array}{l}\text { - Fast access to the project data in } \\
\text { submitted views and } \\
\text { multidimensional reports } \\
\text { - Higher transparency of the } \\
\text { project due to improved reporting } \\
\text { and documentation } \\
\text { - Support in creation of the lessons } \\
\text { learned documents } \\
\text { - Shortening the time of preparing } \\
\text { individual documents through } \\
\text { developed templates }\end{array}$ \\
\hline
\end{tabular}

\section{Criteria of the choice of an information system for the project management}

The list of functions presented in Table 1 is not closed yet. It only shows which functions are offered by contemporary software supporting project management.

In some cases, the level of expansion of information tools enables, among others, management of the whole portfolio of projects. It allows communication among employees with the use of modern forms of transmission (electronic mail, chat, audioconferencing, videoconferencing, instant messaging, discussion forums, newsletters, project weblogs, enterprise information portals, workflow systems, desktop and realtime data conferencing, electronic meeting system, electronic whiteboard [26, 27]). Drawing up additional checklists or even the management of relations with clients is feasible.

The knowledge of the basic functionalities (Table 1) and advantages of ISfPM (Table 3) is the first step in the procedure of choosing appropriate software.

However, the knowledge of general functions itself should not be the basis for the selection of the system.
This would cause a situation where to secure oneself for the future in view of possibly necessary functionalities of the system, excessively expanded programs would be chosen, i.e. the programs that are more complex in servicing and often contain unused functions.

Project managers or higher management of the organization should first, fully understand the specificity and scope of implemented projects and then determine the actual needs and requirements in relation to the software, and subsequently indicate the functionalities needed for the improvement of activities undertaken within the projects.

Subsequently, in order to facilitate the choice of appropriate software we could qualify the project, because of the level of its complexity, to one of the three groups:

1) Simple - short-term projects (up to three months), with simple tasks which require the basic support in management and involvement of capital up to 100 thousand PLN,

2) Moderately advanced - medium (up to one year) projects, characterized by the average size and scope of works, requiring a more comprehensive, though not complex yet, support in management, with the costs up to 10 million PLN,

3) Advanced - long-term (over one year) and complex projects which require a comprehensive support in management, generating costs above 10 million PLN.

The determination of the level of complexity of projects should result from the evaluation of the basic parameters of the project, i.e. time, scope, and cost.

In the case of proper interpretation of the level of project complexity, and qualifying it to one of the three mentioned groups, it becomes possible to better adjust the software to the needs of the project manager and team.

The least complicated projects generally do not require advanced information systems. Sometimes, there is no need to implement any additional solutions, apart from the tools already applied in organizations. In the case of such projects, the support in management may be reduced to checking if the assigned tasks accomplishment deadline is not exceeded. Other functions, such as reminders, and the possibility to share the information with other participants of the project should depend on, among others, the necessity of cooperation among the team members. For long-term projects, within this group of complexity, it may be necessary to draw up a schedule to support and facilitate the work and control.

Projects of the second level of complexity require more support, which is connected with the need to use additional functionalities, such as a possibility to draw up schedules and manage the tasks, the comprehensive management of resources, especially human resources, including, at times, communication through applied software and a possibility to analyse risks within the project. The schedules are presented, not only in the tabular form, but also in the Gantt chart. The software supporting the projects from the second complexity level differs from the one for simple projects in the way of task assignment, the level of determined responsibilities, 
and methods of control of the project work implementation. The use of ISfPM should be the answer to the needs of coordination of numerous tasks with a clearly specified deadline, which requires the simultaneous work of several people e.g. on one document.

For projects of the highest level of complexity, the advanced ISfPM functions are useful. Apart from the possibility of time control, the management of people and tasks, there are the following indispensable functions: the analysis of the critical path, determination and control of the budget (the Earned Value analysis), risk analysis within the project, and the exchange of documents and drawing up reports. For such projects, the ISfPM facilitates both the project preparation and control of its course, and verification of the compliance of the basic plan with the results.

Whenever it is not possible to ascribe a specific project to one of the three levels of complexity (even after the analysis of its basic parameters), attention should be paid to the values of individual characteristics. It may appear that despite the simplicity of the performed tasks, one of the basic parameters of the project is conditioning the need to apply additional functionalities.

However, categorizing the project to an appropriate level of complexity is important due to the efficacy and efficiency of its implementation. When the project is qualified to an improper level of complexity and consequently the choice of an improper ISfPM, it may appear that a part of the work was redundant and additional activities for theoretical improvement of the project were undertaken unnecessarily.

Supplementary verification of the value of the basic parameters of the project will not always be sufficient. In such a situation, it is good practice to make an additional analysis of the factors presented in Table 4. The determination of additional factors consists of a detailed analysis of the basic parameters of a given project and results from classification of projects on account of the level of complexity.

The factors indicated in Table 4 are not the only factors that can be considered while selecting an appropriate ISfPM. Not infrequently, the specificity of the project affects the determination of additional variables which can also contribute to the choice of a concrete system.

To determine additional characteristics of ISfPM, it is worthwhile to check the detailed parameters of specific programs in the lists available in the network [28]. There are many available pages that enable a comparison and analysis of separate systems as well as simple training courses about recommended programs.

The studies conducted regularly in Poland by portal $4 \mathrm{pm} . \mathrm{pl}$, each time on a sample of over 1200 respondents, show a list of important traits that contribute to a positive or negative evaluation of applications used in project management. Particularly on portals in English (portal visual.ly), we can find a lot of information about the programs which support project management, about their possibilities, advantages and disadvantages.
Table 4. Additional factors helpful for the choice of ISfPM (own work based on [23, 24, 27, 29, 30, 31]).

\begin{tabular}{|c|c|}
\hline Factor & Description of the factor \\
\hline $\begin{array}{l}\text { Time needed to } \\
\text { prepare the } \\
\text { project }\end{array}$ & $\begin{array}{l}\text { - It may be: short (up to two weeks), } \\
\text { average (up to three months), long } \\
\text { (above three months) } \\
\text { - More complex, longer projects } \\
\text { require more time to prepare from } \\
\text { the level of assumptions, through } \\
\text { determination of necessary } \\
\text { resources, drawing up a schedule } \\
\text { and transforming it into a plan and } \\
\text { pointing to a risk (such projects are } \\
\text { included in the second group } \\
\text { requiring more support or the third } \\
\text { group requiring a complex support) }\end{array}$ \\
\hline $\begin{array}{l}\text { Type and } \\
\text { amount of } \\
\text { obtained results }\end{array}$ & $\begin{array}{l}\text { - Object, product or service are the } \\
\text { distinguished types of obtained } \\
\text { results } \\
\text { - The result may be either single or } \\
\text { multiple (multiproduct) } \\
\text { - The less complicated the results } \\
\text { and the lower the input of work, the } \\
\text { lower a given project should be } \\
\text { qualified }\end{array}$ \\
\hline $\begin{array}{l}\text { Level of } \\
\text { innovation }\end{array}$ & $\begin{array}{l}\text { - There are non-innovative projects } \\
\text { or those of a high, average or low } \\
\text { innovation } \\
\text { - Projects of a high degree of } \\
\text { novelty, especially those orientated } \\
\text { to products, require a higher } \\
\text { information support and should be } \\
\text { counted among advanced projects }\end{array}$ \\
\hline $\begin{array}{l}\text { Number of } \\
\text { involved } \\
\text { workers }\end{array}$ & $\begin{array}{l}\text { - Increased number of workers } \\
\text { increases communication } \\
\text { difficulties }\end{array}$ \\
\hline $\begin{array}{l}\text { Need for } \\
\text { communication }\end{array}$ & $\begin{array}{l}\text { - It may be constant, occasional or } \\
\text { rare } \\
\text { - Requirements posed to ISfPM are } \\
\text { higher with more employees } \\
\text { involved in the project or with a } \\
\text { higher on-going communication } \\
\text { between members of the project } \\
\text { team }\end{array}$ \\
\hline Documentation & $\begin{array}{l}\text { - It may be advanced (necessity of } \\
\text { mutual development), medium- } \\
\text { advanced (possibility of mutual } \\
\text { development), simple (without } \\
\text { cooperation) } \\
\text { - Choice of programmes supporting } \\
\text { the team work is pointless if new } \\
\text { documents are not drawn up during } \\
\text { the cooperation and the team does } \\
\text { not work on such documents }\end{array}$ \\
\hline $\begin{array}{l}\text { Required level } \\
\text { of control }\end{array}$ & $\begin{array}{l}\text { - It may be complete, partial or may } \\
\text { be confined only to supervision of } \\
\text { time (simple projects) } \\
\text { - Average-advanced projects } \\
\text { require: verification of terms and } \\
\text { costs, control of implementation of } \\
\text { tasks and their correct performance } \\
\text { - Advanced projects require: } \\
\text { additional reports, supervision of } \\
\text { direct work with documents, control } \\
\text { of the accomplishment of tasks and } \\
\text { budget }\end{array}$ \\
\hline
\end{tabular}


An important criterion of the choice of ISfPM is the system's architecture. The software installed on the local server and users' computers enable work without the need to be connected to the mains. Yet, it requires installation on each computer, which usually confines the possibility of group work. The tools available due to Web or SaaS solutions considerably facilitate the cooperation between the project participants. In certain cases, their drawback is the necessity to be on-line, because these are programs, which in other situations, will not be functioning.

The cost of the purchase, and maintenance of the system, is a subsequent determinant in the choice of support for project management information. Some available systems are completely or partly free of charge. In the latter case, we should pay special attention to users' opinions, level of data protection and limitation of the package, especially in the case of gratuitous programs to a specific functionality level or the number of users. These programs are often the best solution for the management of simple projects or those of a medium level of complexity, expressed in the number of tasks, resources and users. On the other hand, choosing paid software, apart from checking its functionality and installation mode, we should pay attention to the payment form and licensing rules. Some of the available ISfPM should be paid on a one-off basis during the purchase, whereas other ones use a subscription system, e.g. monthly fees for use. Otherwise, there are hybrid solutions, which use both payment forms at the same time. In order to carry out a complete and reliable cost analysis, apart from the licencing form and licence purchase cost, we should consider all other components of the implementation costs, i.e. the cost of actual implementation, cost of the purchase of additional software and hardware, cost of training courses, external services and connectors. The buyer should also be aware of some hidden costs depending on the licensing form, such as separate purchase of the carrier and licence to use some of the software, the additional lease of the licence for a specific time, fixed-time access to the www service etc. The final decision for the choice of the system should be guided by both its functions and total costs connected with its purchase, implementation and maintenance.

If no proper software is found, support through a dedicated solution (DTaP) is possible. Preparation of the question should then be preceded with a precise analysis of available solutions and an additional attempt to use several exemplary systems, both free of charge and payable. A dedicated solution usually generates much higher costs and a longer time of waiting for the delivery of the package, as compared to ready-made systems.

From the point of view of some organizations, an important aspect within the choice of an appropriate ISfPM is also the possibility of simultaneous management of many projects - a portfolio or a program of projects [32]. Only payable software exhibits such functionality, therefore before making the final decision, we should first consider if this function is important for the organization.
The four-level model of ISfPM maturity presented in section 3 is also practically very important for the implementation of information support for project management.

Firstly, it shows which requirements - gradually higher and higher - may be posed to ISfPM. Subsequently it shows the complexity of the process of implementing such a system. The individual level actually does not require any implementation efforts, and implementation of a fully functional system based on the Web interphase lasts exactly as long as putting the plug of the network cable of a special mini server supplied to the company into the socket of the local company network. Implementation of more advanced solutions usually does not exist without high work input. Preparation from scratch, testing and implementation of the dedicated software to the management of very complex projects may last for many months. The ISfPM maturity model may also be the basis for evaluation of the quality of the systems to be implemented.

To facilitate the choice of ISfPM, the rankings and comparisons of information solutions that support project management are drawn up. One of them, worthy of attention, is the regularly published report of the advisory company Gartner Inc., i.e. the Gartner magic square [33]. The report shows the position of individual systems and synthetically characterises each of the solutions available on the market.

\section{Conclusions}

The choice of the proper software for the organisation, or also sometimes for a specific project (DTaP), is one of the conditions of effective management of projects.

ISfPMs are used to support the preparation, implementation and completion of projects, and not their complete development.

The knowledge of the basic functions of ISfPM should be the first step in the process of choosing appropriate software.

It is very uncommon to have the possibility to assemble a fully functional system, especially for specific use (constructional projects, scientific projects, research and development projects) from one producer's offer. Therefore, the quality and reliability of connections among the modules gain greater importance.

For the same reason, the producer's market position drops and the prospects for the development of a specific product are decreasing. The customers will only expect from the suppliers some technical support and help in emergency situations. They will frequently have to apply for the dedicated solutions to niche companies supplying specialist modules.

Modular structure of the systems also allows an easier selection of software in view of its output. Specific gaps will be supplemented by the third companies' software.

In practice, the restrictions of generated reports disappeared, because it has become increasingly common to use standard relative databases. The professional SQL operator will be able, using the 
commonly available software of the clients' databases, to search for any information and prepare any statements.

Implementation of methodologies in ISfPM is becoming less and less important. The ready systems usually offer a set of instruments used in project management, while more sophisticated methodological needs will satisfy the tools and dedicated packages.

The success of seemingly similar projects depends on the applied methods and specific tools as well as supporting, with information, systems for the management of undertaking work. However, no ISfPM will ever become a panacea for all the problems encountered by project managers and their contractors conducting the projects and

The current management occurring in the network process of decision-making is based not only on the fast acquisition of checked information, but also on knowledge. The most effective project approach is the one where people, using both the organization's information and knowledge resources, and implementing particular project procedures (using properly selected information instruments), construct gradually the intellectual capital and consequently acquire a new value of the organization functioning [23].

\section{References}

1. W. Chmielarz, Zarządzanie projektami@ @ rozwój systemów informatycznych zarzadzania (Wydawnictwo Naukowe Wydziału Zarządzania Uniwersytetu Warszawskiego, Warszawa, 2013)

2. J. Kisielnicki, Zarządzanie projektami. Ludzie procedury - wyniki (Oficyna a Wolters Kluwer business, Warszawa, 2011, 264-280)

3. E. Sońta-Drączkowska, Zarządzanie wieloma projektami (Polskie Wydawnictwo Ekonomiczne, Warszawa, 2012, 11-28)

4. W. Curlee, R. L. Gordon, Successful Program Management: Complexity Theory, Communication and Leadership (CRC Press, Boca Raton, 2014)

5. M. Trocki, Nowoczesne zarządzanie projektami (Polskie Wydawnictwo Ekonomiczne, Warszawa, 2012, 416-432)

6. G. R. Heerkens, Jak zarządzać projektami (RM, Warszawa, 2003, 127)

7. T. Schmidt, Strategic Project Management Made simple. Practical Tools for Leaders and Teams (John Wiley \& Sons, Inc., Hoboken, 2009)

8. A. Bitkowska, Zarządzanie procesami biznesowymi w przedsiębiorstwie (Wizja Press \& IT, Warszawa, 2009)

9. P. Cabała, Metody doskonalenia procesów zarządzania projektami worganizacji (Difin, Warszawa, 2016)

10. J. Charvat, Project Management, Methodologies Selecting, Implementing, and Supporting Methodologies and Processes for Projects (John Wiley \& Sons, Inc., Hoboken, 2003)

11. V. LÉvÁrdy, T. R. Browning, IEEE Trans. on Eng. M. 56, 600-620 (2009)
12. W. Chmielarz, Information Technology Project Management (Wydawnictwo Naukowe Wydziału Zarządzania Uniwersytetu Warszawskiego, Warszawa, 2015)

13. K. Schwalbe, Information Technology Project Management $8 e$ (Cengage Learning, Inc., Boston, 2015)

14. M. Wirkus, A. Lis, Zarzadzanie projektami badawczorozwojowymi (DiFin, Warszawa, 2012)

15. M. Trocki, Metodyki zarządzania projektami (Bizarre, Warszawa, 2011)

16. Peter W.G. Morris, J.K. Pinto, The Wiley Guide to Project, Program \& Portfolio Management (John Wiley \& Sons, Inc., Hoboken, 2007)

17. H. Kerzner, Project Management: A Systems Approach to Planning, Scheduling, and Controlling Eleventh Edition (John Wiley \& Sons, Inc., Hoboken, 2013)

18. S. Y. Chadli, A. Idri, J. N. Ros, J. L. FernándezAlemán, Juan M. Carrillo de Gea, A. Toval, Software project management tools in global software development: a systematic mapping study (SpringerPlus, https://www.ncbi.nlm.nih.gov/pmc/ articles/PMC5121116/)

19. M. A. B. Ilyas, M. K. Hassan, M. U. Ilyas, PMIS: boon or bane? (Paper presented at PMI ${ }^{\circledR}$ Global Congress 2013-EMEA, Istanbul, https://www.pmi.org/ learning/library/project-management-informationsystems-overviews-5813)

20. M. Juchniewicz, Dojrzałość projektowa organizacji (Bizarre, Warszawa, 2009)

21. M. Trocki, Zarzadzanie wiedza $w$ projektach. Metodyki, modele kompetencji i modele dojrzałości (Oficyna Wydawnicza Szkoły Głównej Handlowej, Warszawa, 2011)

22. S. Gasik, Dojrzałość systemów zarządzania projektami (Sybena Consulting, Warszawa, www.sybena.pl/ dokumenty/MD-Model-dojrzalosci-systemow-ppmV1.0.pdf)

23. A. Jaskanis, M. Marczewska, M. Darecki, Zarzadzanie projektami $w$ administracji publicznej (PRESSCOM, Wrocław, 2015, 235-266)

24. P. Poturalski, Kluczowe aspekty wdrażania narzędzi do zarzadzania projektami (MDDP Business Consulting, Warszawa, http://www.mddp-bc.pl/know-how/ narzędzia-it-wspierajace-zarzadzanie-projektami/ art,91,kluczowe-aspekty-wdrazania-narzedzi-dozarzadzania-projektami.html)

25. PM Network 12 (2006)

26. K. Kandefer-Winter, O. Nadskakuła, Komunikacja w zarządzaniu projektami (CedeWu, Warszawa, 2017)

27. K. Riemer, C. Steinfield, D. Vogel, Elec. Mark. 19, 183 (2009)

28. D. B. Stang, M. Light, T. Jones, Magic Quadrant for Project Portfolio Management, Worldwide (www.gartner.com/doc/3728917/magic-quadrantproject-portfolio-management) 
29. P. Simon, Project management tips for a decisionsupport system implementation

(TechTarget Network,

http://searchdatamanagement.techtarget.com/answer/Pr oject-management-tips-for-a-decision-support-systemimplementation)

30. P. Simon, The Next Wave of Technologies. Opportunities in Chaos (John Wiley \& Sons, Inc., Hoboken, 2010)
31. A. C. Uzialko, Choosing Project Management Software: A Buyer's Guide (Business News Daily, http://www.businessnewsdaily.com/9976-projectmanagement-software-buyers-guide.html)

32. Project Management Institute, Project Portfolio Management. A View from the Management Trenches (John Wiley \& Sons, Inc., Hoboken, 2009)

33. P. Wyrozębski, Zarządzanie wiedza projektowa (Difin, Warszawa, 2014) 